\title{
O DISCURSO DA SUSTENTABILIDADE NAS REDES SOCIAIS
}

Lara Correa Ely

\section{RESUMO}

O presente artigo traz uma reflexão sobre o papel das redes sociais na construção de uma ideia coletiva de sustentabilidade. Mostra como os discursos proferidos nestes espaços de comunicação digital são capazes de fomentar ações e práticas de mudança na vida real. Verifica, ainda, se a partir do discurso jornalístico na web há engajamento em ações no ambiente externo às mesmas. A resposta para este problema é apresentada a partir de uma análise teórica sobre redes sociais, sustentabilidade e análise de discurso, respectivamente. $\mathrm{O}$ estudo destaca a necessidade de formatação de novas estruturas narrativas para a abordagem da sustentabilidade nas redes sociais digitais.

Palavras-chave: Redes Sociais; Sustentabilidade; Discurso; Interação; Web

\section{THE DISCOURSE OF SUSTAINABILITY IN SOCIAL NETWORKS}

\begin{abstract}
This article reflects about the role of social networks in the construction of a collective idea of sustainability. It shows how the media speeches in these spaces of digital communication are capable to create actions and practices to promote changes in real life. It also wants to verify if the journalistic discourse on the Web contributes for engaging people in actions in the external environment. The answer to this problem is presented from a theoretical analysis of social networks, sustainability and discourse analysis, respectively. The study highlights for the need of establishing new narrative structures to speaks about sustainability in digital social networks
\end{abstract}

Key-words: Social Networks; Sustainability; Speech; Interaction; Web 


\section{Introdução}

O que torna um formador de opinião influente nas redes sociais digitais quando o assunto é sustentabilidade? Abordar essa questão de forma neutra e informativa, sem parecer tendencioso ou engajado, é um desafio para quem escreve sobre o tema. E como a crescente presença de pautas sobre a sustentabilidade na mídia permite estabelecer uma quantidade maior de conexões, o público receptor amplia-se também. Redes sociais como Blogs, Twitter e Facebook colaboram para que causas e marcas estejam mais próximas de seus públicosalvo. Porém, a ampla visibilidade do tema parece não ser diretamente proporcional ao seu entendimento ou real apropriação.

Nesse sentido, o presente estudo traz uma reflexão sobre o papel das redes sociais na construção de uma ideia coletiva de sustentabilidade. Pretende, com isso, identificar se a partir do discurso jornalístico na web há engajamento em ações no ambiente externo às mesmas. A resposta para este problema será buscada a partir de uma reflexão teórica sobre redes sociais, sustentabilidade e análise de discurso, respectivamente.

Como suporte teórico para compreender os métodos de pesquisa na Internet, os subsídios provêm das autoras Lúcia Santaella, Suely Fragoso, Raquel Recuero e Adriana Amaral. Os teóricos Enrique Leff e Augusto de Franco oferecem suporte teórico para compreender de que forma os estudos sobre sustentabilidade relacionam-se com a comunicação. E Patrick Charaudeau, Eliseo Verón e Milton José Pinto, por sua vez, são referenciais para entender a dinâmica da análise de discurso.

Um breve olhar sobre os estudos do ambiente digital permite identificar que, com a explosão das ferramentas de comunicação digital, há mais registros da memória presente. Diante disso, coloca-se a questão sobre o grau de inovação dessas narrativas e sua utilidade. Esse conteúdo comentado e informado nas multiplataformas pode ser novo? A linguagem é a mesma, ou há inovação? O sujeito da informação se transforma com muito mais velocidade, em categorias com multipossibilidades de conexão. Resta saber se os conteúdos dessas mensagens também passam pelo mesmo nível de transformação.

Refletir para essa dinâmica da comunicação nas redes significa estudar o que Lúcia Santaella (2001) define como interfaces do meio com o contexto. Segundo a autora, este tipo de estudo propõe uma reflexão do impacto de uma nova mídia sobre as interações e estruturas sociais já existentes. "As mídias são também estudadas não como simples canais para 
transmitir informações, mas como formadoras de novos ambientes sociais, como é o caso atual das comunidades virtuais no ciberespaço” (SANTAELLA, 2001, p. 93).

Segundo a autora (2001), a análise de redes sociais é utilizada para entender fenômenos sociais e comunicacionais distintos que acontecem nos objetos pertinentes à Internet, como sites, redes sociais, comunidades on-line, blogs, entre outros. Embora muito já tenha sido dito em relação ao tema, já houve quem duvidasse que a Internet poderia servir como campo de pesquisa.

Um dos principais desafios para o estudo da comunicação na web é que a mesma não pode ser capturada por um quadro individual, ela é baseada em quadros estanques, mas ela em si está em constante fluxo. Fragoso, Recuero e Amaral inspiram-se na obra de Costigan (1919, p. 19) para destacar que a ciência social produzida sobre a Internet se divide basicamente em duas categorias: a primeira é relativa à busca e recuperação de informações a partir de enormes bancos de dados, e a segunda diz respeito à capacidade de comunicação interativa presente na rede.

Segundo as autoras, entre as tendências da pesquisa de Internet destacadas na década de 90 estão: a moda (denominada hype), a polarização do real versus o virtual e o entendimento da Internet como esfera autônoma, distinta do real. Já na segunda metade dos anos 90, começam a aparecer estudos que relacionam e comparam a Internet a outras mídias (POSTHILL, 2010, on-line apud FRAGOSO, RECUERO E AMARAL, 2011, pg. 36). A partir dos anos 2000, a tendência dos estudos é de se voltarem para a descrição e compreensão dos objetos dentro de suas próprias dinâmicas, apropriações e lógicas.

\section{O engajamento nas redes sociais}

A periodização dos estudos na web no contexto internacional, proposta pelo pesquisador Barry Wellman, em 2004 (FRAGOSO, RECUERO E AMARAL, 2011, p.36) divide-se em três fases. A primeira é caracterizada pela dicotomia entre autores utópicos e distópicos. Segundo Wellman, nessa fase predominava um tipo de narrativa na qual parecia que o mundo da comunicação teria surgido com a Internet.

Na segunda fase, as pesquisas começam a utilizar a sistemática da documentação para coleta e observação tanto dos usuários como dos tipos de usos e práticas sociais. Na terceira fase, a abordagem teórico-metodológica está focada na análise de dados a partir de pesquisas que levantam reflexões mais densas a respeito dos padrões de conexões, personalização e comunicação (FRAGOSO, RECUERO E AMARAL, 2011, p. 37). 
O estudo das redes sociais na Internet é retomado como abordagem principalmente após o surgimento dos sites de rede sociais na Internet (BOYD e ELLISON, 2007). Esses sites são caracterizados pela construção de um perfil com características identitárias (que são percebidos como os atores sociais) e com a apresentação de novas conexões entre esses perfis (as arestas da rede social). Como a Internet possui ainda a característica da pertinência das interações sociais, essas são mais facilmente percebidas, gerando novas oportunidades de estudo.

Muitos dos discursos presentes hoje nas redes sociais são feitos em torno de desabafos pessoais, de protestos, manifestos, de expressão de sentimentos como ocorriam, antigamente, com panfletos ou protestos nas ruas. Poder-se-ia dizer que as redes sociais crescem e ampliam território na medida em que os movimentos populares perdem força nas ruas e ganham destaque no ambiente virtual. A ideia aqui apresentada não é de que as redes substituem esses movimentos, mas sim que atuam na articulação, apoio, fomento e aproximação de causas coletivas. As redes sociais, pelo seu alcance, definiram-se como força de mobilização e têm ganhado destaque por servir de ferramenta de comunicação para manifestantes de distintas causas.

Nesse ambiente tecnológico, a informação é a principal moeda de troca. As redes sociais digitais são espaços que permitem a interação de diferentes tipos, gêneros e categorias de perfis. Nelas, misturam-se histórias provenientes das mais diversas fontes narrativas. Um internauta interessado em atualizar-se sobre notícias de sustentabilidade pode seguir no Twitter, entidades públicas e privadas ligadas ao tema, bem como formadores de opinião desta área e outros amigos também interessados no assunto. Quem estabelece o filtro a respeito das informações presentes na rede é o próprio receptor, que irá apropriar-se e passar adiante apenas aquelas mensagens que forem familiares ao seu mapa conceitual. Ou seja, as informações presentes na rede somente farão sentido para aquele internauta que encontrar na mensagem online alguma referência mental dentro do seu imaginário pessoal.

Uma mensagem - para ter efeito neste tipo de ambiente - deve estar inserida no processo de interação e comunicação com os usuários da rede. É por isso que o perfil influenciador tem um papel importante neste meio, pois possui uma força de articulação das informações maior do que a maioria dos usuários. Esta sistemática repete, em uma esfera tecnológica, o mesmo processo que ocorre em qualquer tipo de rede social real. Segundo matéria publicada na revista Época (maio/2010), há pelo menos cinco grandes grupos de 
formadores de opinião presentes nas redes sociais. São eles: os artistas, os pensadores, os empreendedores, os engajados e os alavancados

Os artistas são jovens de talento que foram revelados pelas redes e agora fazem sucesso também nas mídias tradicionais. Um exemplo é o cineasta Esmir Filho.

Os pensadores são pessoas que escrevem análises, pensamentos, críticas com ou sem humor, e servem como distribuidores de conselhos e informações relevantes. Neste grupo estão o filósofo Pierre Lévy e a pesquisadora Raquel Recuero.

O empreendedor é aquele que montou sua própria rede social ou que usa as comunidades online para fazer negócios, tal como o criador do Twitter, Biz Stone, ou o fundador do site Apontador, Rafael Siqueira.

Os engajados são aqueles que usam o poder mobilização das redes para criar campanhas ou movimentos em prol de causas sociais, culturais ou ambientais, como a publicitária Cristiana Soares e o escritor Fabrício Carpinejar.

E, por fim, os alavancados são pessoas comuns que usam o poder multiplicador das redes para realizar ações extraordinárias. No ambiente da comunicação digital, essa liderança e poder de formar opinião são mais facilmente associados àqueles que detêm conhecimento das ferramentas.

Aqueles que conhecem melhor a cultura e o funcionamento cotidiano deste ambiente lideram mais facilmente. Artifícios de linguagem, como a retórica, o humor, o jogo de palavras, também são estratégias discursivas empregadas pelos formadores de opinião para melhor atrair seu público. A análise de discurso da sustentabilidade feita no ambiente das redes sociais deve levar em conta alguns fatores que liguem o emissor ao receptor. São fatores como a origem, o destino, as intenções e a recepção do discurso que ajudam a definir como ocorre essa interação. Interessa, aqui, saber quem está falando, para quem está sendo dito, em que contexto essa informação é produzida e recebida.

É possível refletir ainda sobre as interpretações e os usos dados a essa informação, e os efeitos dela fora do ambiente específico da rede. Um fato que comprova isso seria o uso da \#hashtag (expressão que serve para reduzir fatos ou sentimentos) fora do Twitter. Trata-se de um exemplo desta interferência de linguagem de uma rede social em outras formas de comunicação.

Há ainda outros casos recentes que permitem verificar como as informações recebidas pelos usuários das redes ocasionam mudanças comportamentais na vida dos indivíduos. A ação da ONG Massa Crítica em Porto Alegre, diante do atropelamento de ciclistas na cidade, 
no dia 25 de fevereiro de 2011, levou centenas de internautas a se mobilizarem e participarem de um ato de repúdio à violência no trânsito.

Outros exemplos são: os protestos contra a corrupção no dia 7 de setembro de 2011, organizados em todo país pela Internet, com registro de grande público; os movimentos de jovens no Egito, e na Tunísia; a ideia de Wikicidade, onde o indivíduo pode mostrar, a partir de um ambiente digital, aquilo que ele gostaria de melhorar no seu ambiente local, e a campanha "Eu Curto, Eu Cuido", onde a Prefeitura de Porto Alegre divulga nova coleta seletiva de lixo e apropria-se da linguagem do Facebook para envolver os moradores da capital gaúcha no cuidado com o meio ambiente. São inúmeros os exemplos de como as tecnologias de informação e comunicação proporcionam novas formas de interação e novos modos de apropriação da linguagem.

\section{Era das conexões topológicas descentralizadas}

Escolhidas como pano de fundo deste estudo, as redes sociais digitais são espaços onde o conceito da sustentabilidade se espalha a cada dia. $\mathrm{O}$ assunto integra um novo ecossistema midiático em formação e desenvolvimento. Estão conectados a este espaço os meios de comunicação analógicos e os meios digitais. Segundo Walter Lima (2011, p.24), as redes possuem “conexões topológicas descentralizadas e de baixa hierarquia, fornecendo novas possibilidades de consumo de conteúdo e alterando a relação estabelecida (...) entre a audiência e suas preferências informacionais". Ao contrário de uma visão comum generalista, as mídias sociais estão conectando mais os internautas a questões de engajamento humanitário e ambiental.

Se por um lado existe a tendência de se dizer que o uso de novas tecnologias de comunicação e relacionamento isola as pessoas, fazendo-as adotarem comportamentos mais passivos e individualistas, há a corrente dos que defendem as redes como fatores de mobilização social. Este grupo acredita que, ao aglutinar e agrupar indivíduos de interesses comuns, ao invés de isolá-los, as redes potencializam vozes antes solitárias e pluralizam o espaço da opinião pública. Dessa estrutura informacional emergem possibilidades de estabelecer diferentes tipos de relacionamento entre emissor de conteúdo informativo e a audiência.

Para compreender um pouco mais sobre este contexto discursivo, é importante levar em conta o fato de que, muitas vezes, a fala sobre sustentabilidade nas redes ocorre com a finalidade de descrever projetos de responsabilidade social empresarial ou cidadania 
corporativa. Embora se use aqui a palavra "sustentabilidade", é reconhecido que, em muitos pontos, os termos são sinônimos. Ambos referem-se aos mesmos aspectos dos negócios: a gestão global da empresa, o relacionamento com os públicos relacionados, o impacto sobre o meio ambiente e sobre a comunidade local, entre outros fatores (LEFF, 2010). Porém, enquanto o emprego do termo responsabilidade social corporativa é mais direcionado a projetos e programas, o termo sustentabilidade incorpora valores que devem permear toda a estrutura completa de uma organização.

Partindo desses pressupostos, é possível identificar uma forte presença do discurso sobre sustentabilidade construído pela lógica do mercado, a partir de um olhar proveniente dos setores de marketing e propaganda. Neste âmbito, o foco está na atuação positiva em relação à instituição que realiza as ações: qualquer tipo de ação ou pronunciamento que ocorra será sempre em defesa da imagem da própria instituição. Por outro lado, existe o discurso por parte das entidades que atuam em defesa de causas sociais e ambientais. O mesmo é manifestado através de mensagens que se propõem a realizar alertas, despertar polêmicas, questionar ações políticas, fazer denúncias, etc. Atuam, portanto, no sentido de mobilizar os internautas em prol de campanhas e ações promovidas pelas próprias.

Aqui, cabe ressaltar que uma vez que o contrato de fala está determinado, cabe a cada texto especificar a sua estratégia. Charaudeau (2006) destaca que, do ponto de vista das estratégias peculiares do discurso, diferentes textos utilizam os mesmos procedimentos e têm particularidades do ponto de vista enunciativo, narrativo e argumentativo.

Pode-se afirmar que o discurso sobre a sustentabilidade é representado pelas produções textuais e narrativas que abordam o tema tanto pelo viés do discurso publicitário, jornalístico, político, ideológico, quanto pelas demais formas discursivas. Ao observar o estilo do discurso sobre sustentabilidade mais presente nas redes sociais, é possível identificar que o mesmo caracteriza-se por um comportamento elocutivo, ou seja, o locutor posiciona seu dito em relação a si mesmo, desvelando a sua própria posição, a sua avaliação e as suas emoções.

De acordo com Charaudeau, o anunciador anuncia-se por uma tomada de posição apreciativa e o destinatário não é explicitamente solicitado como em um comportamento alocutivo. Ele ainda está em posição de expectador-testemunha, mas é chamado a compartilhar a euforia do anunciador.

Os formadores de opinião são denominados sujeitos da emissão dessas mensagens. Eles figuram nas principais redes sociais digitais, tais como Twitter, Facebook e Blogs, são pessoas físicas ou jurídicas identificadas com a causa ambiental ou de alguma forma 
sensibilizadas com os princípios da ecologia, do consumo consciente, do marketing verde e da responsabilidade social. São pessoas que, de alguma forma, possuem em comum o engajamento em causas coletivas e utilizam a Internet como ferramenta de mobilização a favor de suas crenças. Ou, por outro lado, são organizações, empresas e entidades que aproveitam da onda das redes sociais para inserir o discurso sobre seus produtos, serviços, ações ou valores.

Os receptores da informação, por sua vez, são denominados sujeitos destinatários. São usuários das redes de maneira geral, stakeholders (os públicos de interesse de uma empresa ou entidade), e principalmente, aqueles que estão identificados com a causa, através da conexão com assuntos de interesse relacionado ao tema da sustentabilidade. Nas redes sociais, todas essas formas discursivas estão presentes simultaneamente.

A ausência de limites sobre temas e o caráter de livre trânsito quanto às formas de interação permitem que indivíduos portadores de perfis totalmente distintos, inclusive no que tange a fatores ideológicos, sociais e econômicos, estejam articulados no mesmo ambiente virtual, simultaneamente. Este modelo de topologia da rede social digital permite um estabelecimento de um maior número de conexões entre um perfil com seus públicos associados.

De acordo com Fragoso, Recuero e Amaral, uma rede social, por si, é uma metáfora estrutural

De um lado estão os nós (ou nodos). De outro, as arestas, conexões. Enquanto os nós são geralmente representados pelos atores envolvidos e pelas suas conexões na Internet, as conexões são mais plurais em seu entendimento. É possível compreender essas conexões como as interações que são construídas entre os atores (como por exemplo, os comentários de um blog e as mensagens do Twitter) e como aquelas que são proporcionadas e mantidas pelo sistema (como adicionar um amigo no Facebook) (FRAGOSO, RECUERO E AMARAL, 2011, p 115).

Esses canais podem fluir, para dentro, o capital humano e social que necessitam. Um exemplo é como as ações externas às redes sociais acabam incorporando valores e símbolos das redes sociais.

\section{Desvendando estratégias discursivas}

Dentro dessas redes, existe um resgate de pertencimento: mais pessoas têm voz para falar de assuntos que lhes interessam com maior ou menor conhecimento de causa, sem hierarquia e com pluralidade de olhares. Essa é a ideia defendida por Augusto de Franco (2008) no livro Escola de Redes. Uma vez parte de um grupo, mais forte e mais ligada a uma 
determinada causa a pessoa fica. Esta situação permite ao cidadão/internauta a noção de ser mais engajado, por estar interagindo diretamente com aquele tema, através de ações propostas pelas próprias redes, como o "curtir" ou o "compartilhar" no Facebook, ou por convidar os seus contatos para determinado evento e obter confirmações públicas. Ações do tipo call to action, solicitando conteúdos pontuais ao público, se potencializam nas redes, principalmente em momentos específicos como desastres naturais, ou grandes desastres climáticos, por exemplos. Para o autor Milton José Pinto (1999), a interação consiste em interpelar ou estabelecer relações de poder com o receptor, na tentativa de cooptá-lo e de agir sobre ele ou sobre seu mundo, por intermédio. O problema a ser resolvido aqui, pelo emissor, é o de reproduzir hierarquias sociais reconhecidas no interior da instituição em que o processo de comunicação se dá, reforçando-as ou tentando modificá-las, segundo determinada estratégia persuasiva (PINTO, 1999). No caso em questão, a instituição referida seria a própria rede social no qual o discurso está inserido, e as normas são os contratos de convívio préestabelecidos dentro desses espaços.

Algumas estratégias discursivas superficiais são apresentadas com certa frequência na mídia sem que sejam percebidas como engodos. Um olhar mais atento, porém, próprio de um analista de discurso, é capaz de encontrar deslizes, ou indícios que mostram intenções presunçosas de quem emite o discurso. Vamos aos exemplos. Uma organização que acaba de iniciar o tratamento de resíduos e pede aos colaboradores que separem o lixo pode ser chamado de empresa sustentável? A resposta é não.

A sustentabilidade é baseada em práticas que ganham força de acordo com o comportamento e com a história, e não com o imediatismo e com o glamour de uma ação. Ações deste tipo, mais calcadas em efeitos de imagem do que de mudanças sedimentadas, minam a credibilidade e banalizam conceitos importantes, podendo reduzi-los a uma imagem contraditória.

O filósofo e linguista Eliseo Verón estuda a ideologia contida no seio dos discursos. Ele entende os processos de significação como processos de produção de sentido, ou seja, como trabalho social dentro de um conjunto produtivo de sociedade. Para Verón, uma teoria da produção social do discurso não pode limitar-se a um estudo de produção. Ele recorre à leitura, pois nesta o ponto de partida encontra-se situado na recepção. Podemos dizer que há sempre duas leituras possíveis, há duas gramáticas: uma da produção e a outra do reconhecimento, que são exatamente idênticas (VERÓN, 2005). 
De acordo com Verón, o discurso é um espaço habitado por atores, cenários e objetos, e ler é movimentar esse universo, aceitando ou rejeitando suas particularidades. A análise de discurso passa a dar atenção à transformação que os textos sofrem regularmente através das redes sociais, bem como às práticas discursivas próprias da web.

Nota-se que o processo de produção de conteúdo para as redes sociais, de maneira geral, decorre de um processo anterior de comunicação. Provém da elaboração de pautas e apuração de assuntos para outras plataformas midiáticas, como jornais, revistas, televisão, rádio, cinema, propaganda e os próprios veículos de informação online. A partir daí, ocorre uma readaptação de linguagem e as mesmas pautas ganham uma nova formatação para atrair o público das redes sociais.

Em seu livro Discursos Sustentáveis, o economista Enrique Leff organizou inúmeras falas que proferiu em eventos e conferências na área de sustentabilidade. Ali, o autor explica que estes discursos são permeados por "palavras que evocam novas recordações, que invocam novos projetos, que convocam para novos encontros" (2010, p.16). "Estes discursos buscam fazer-se de palavras que se tornem verbo e ação; movimento transformador, diálogo de seres e saberes que bordam um novo tecido social" (LEFF, 2010, p.16). De acordo com Leff, os discursos sobre sustentabilidade desmentem essas correntes que pretendem ajustar o mundo à economia, reorganizá-lo conforme as leis da ecologia, resolvê-lo através da inventividade tecnológica e salvá-lo por meio de uma nova lógica planetária. Ao contrário, o autor entende que os discursos sustentáveis

[...] procuram enraizar-se em novos territórios de vida, decantar-se em novas racionalidades e incorporar-se em novas subjetividades; amalgamar-se em novas identidades, forjar novas técnicas e gerar novos processos produtivos baseados nos potenciais ecológicos e na criatividade cultural dos povos. Estes discursos se armam com saberes que se inscrevem na ressignificação do mundo, que conduzem ao reposicionamento do ser no mundo, à reinvenção de identidades pessoais e coletivas (LEFF, 2010, p.16).

A argumentação e retórica apresentadas acima estão calcadas na vertente da economia ecológica, uma forma de contraponto à economia neoclássica que não reduz os recursos naturais ao valor de mercado. Ela foca na interdisciplinaridade como um fator de diálogo, visando estabelecer conexões entre as múltiplas disciplinas e com foco no mercado. "A partir de uma visão sistêmica, tenta articular a economia com outros sistemas - população, tecnologia, cultura - e abrir um diálogo entre a racionalidade econômica e outros espaços de pensamento, outras disciplinas e outros saberes" (LEFF, 2010, p.28). 
Nesse contexto, cabe ressaltar que a definição do autor para o termo da sustentabilidade relaciona-se com um olhar para o futuro. Para ele, sustentabilidade é "uma maneira de repensar a produção e o processo econômico, de abrir o fluxo do tempo a partir da reconfiguração das identidades, rompendo o cerco do mundo e o fechamento da história impostos pela globalização econômica” (LEFF, 2010, p.31).

A crença no progresso sem limite, o consumo desenfreado, o império do ter sobre o ser foram marcas deixadas pela modernidade no consciente coletivo da sociedade contemporânea. Entre outros fatores, essas são razões que levam Leff (2010) a dizer que vivemos uma crise ambiental. A mobilização de tantos novos atores e interesses sociais para a reapropriação do discurso em relação à natureza é um forte sinalizador de que essa crise afetou o mercado.

Sendo assim, a nova economia descrita anteriormente deverá basear-se em uma rearticulação entre cultura e natureza, calcada pela pluralidade de identidades e transcendendo a uma hibridização entre disciplinas científicas. Ao olhar para as redes sociais, onde saberes acadêmicos e saberes populares encontram-se misturados, Leff encontraria um prato cheio para sua construção teórica.

\section{A influência do virtual nas realidades conectadas}

Para caracterizar esta complexa trama de identidades, estilos, gêneros, técnicas, práticas, tecnologias, mídias e misturas constitutivas dos hibridismos das culturas contemporâneas, Santaella (2008, p. 22) desenvolveu o conceito de ecologia pluralista das linguagens, das práticas e das culturas. Para ela, "a ecologia pluralista na cultura refere-se a uma considerável expansão dos parâmetros que tradicionalmente serviam para definir as produções e práticas de linguagem e comunicação" (2008, p. 22). A ecologia pluralista busca traçar as redes de suas culturas e lógicas operacionais em contextos espaciais, temporais, sociais e ambientais amplamente concebidos. Para a autora, as mídias locativas são o exemplo dessa teoria.

Cunhada por Karlis Kalnins como uma categoria de teste para processos e produtos realizados com as tecnologias emergentes, a expressão "mídias locativas" refere-se a tecnologias baseadas em lugares. Na prática, são as tecnologias sem fio, tecnologias de vigilância, de rastreamento e de posicionamento que permitem que a informação seja ligada a espaços geográficos. Outros dispositivos móveis, além do GPS, que compõem a malha tecnológica das mídias locativas são os telefones celulares, os palms e lap tops sem fio em 
redes Wi Fi, bluetooths, entre outros. Esses dispositivos permitem que as pessoas se localizem e se liguem virtualmente a outros no espaço geográfico e que conectem informação a posições geográficas.

Essas tecnologias da mobilidade, sensíveis aos locais, estão cada dia mais aptas a acessar a Internet, permitindo que a informação seja armazenada e recuperada a partir de bases de dados remotos. A autora chama de "geoanotações" esses projetos que exploram as fronteiras dos espaços geopolíticos das cidades e permitem que pessoas comuns insiram nas paisagens urbanas seu próprio conhecimento social.

Muitos desses projetos têm propósito documental, buscando conectar significados ocultos aos lugares, e resgatando a memória coletiva. "Os projetos de anotação urbana que encorajam as pessoas a postar, em localizações geográficas, histórias pessoais, pensamentos, alguma informação, chamadas para a ação, trocas entre usuários" (SANTAELLA, 2008, p.23). São projetos que resgatam a experiência pessoal de contar histórias, na recuperação da memória coletiva cujo registro se inscreve na contracorrente das histórias oficiais.

A ideia desenvolvida por Santaella trata, em síntese, da construção compartilhada do conhecimento. Estes projetos sinalizam que a Internet não apenas invade o mundo real, mas propõe o enriquecimento de nossa experiência espacial pela sobreposição de camadas de informação - imagens, textos, sons - disponibilizados por dispositivos móveis e computação sem fio habilitados com GPS e alimentados por um intenso espírito comunitário.

Algumas ferramentas on-line e aplicativos para celular são aliados da sustentabilidade. Na medida em que estão conectados com as redes sociais através dos tablets e smartphones, são suportes que estimulam a disseminação da sustentabilidade nas redes sociais. Veja a seguir alguns exemplos de sites e aplicativos descritos no Manual de Etiqueta 3.0 - 65 ideias para enfrentar o aquecimento global e outros desafios da atualidade, encarte publicado pela Editora Abril (2011):

Made in Forest - site de relacionamento que reúne, identifica, organiza e divulga gratuitamente, empresas e serviços ecológicos.

Waterprint - calcula os gastos com a água nas categorias alimentos, bebidas, produtos e itens domésticos.

Fuel - permite armazenar o histórico de abastecimento e calcular o consumo de combustível do automóvel.

$E d d y$ - jogo educativo sobre coleta seletiva e destinação correta do lixo. 
Social Bike - registra rotas, informa velocidade, fornece dicas de segurança no trânsito e permite compartilhar fotos e vídeos do passeio.

Caronetas - estimula a carona entre funcionários de empresas na cidade de São Paulo, com garantias de segurança e controle.

Freecycle - comunidade on-line de troca de objetos entre usuários presente em mais de 5 mil cidades.

Project Noah - ajuda os cientistas a documentar a biodiversidade por meio de aplicativos que registram fotos de plantas e animais.

Outra forma de medir o impacto do tema da sustentabilidade nas redes sociais é observar o comportamento das mídias ditas convencionais. Uma pesquisa realizada pela Revista Imprensa e a MídiaB Auditoria de Imagem (2011) apurou e divulgou o ranking das “Empresas Mais Sustentáveis Segundo a Mídia”. Neste estudo, foi revelado que embora as empresas de tecnologia estejam na ponta do ranking, as ações digitais e o uso de mídias sociais ainda não tiveram impacto no resultado da pesquisa. O motivo é a baixa pontuação do impacto das notícias, levando em conta a visibilidade do veículo e a estrutura da reportagem.

O estudo foi elaborado a partir da análise de matérias publicadas em todas as edições do ano de 2010 das revistas Veja, IstoÉ, Época, CartaCapital, Amanhã-RS, América Economia, Época Negócios, Exame e IstoÉ Dinheiro. A pesquisa verificou os conteúdos das edições e extraiu todas as matérias que abordassem o tema sustentabilidade. As matérias foram classificadas entre os assuntos Ambiente, Transparência, Relações com os Diversos Públicos e Comunidade.

Em 2010, as nove publicações analisadas pela pesquisa totalizavam, juntas, uma área de $120.400 \mathrm{~cm} 2$ dedicada a cobertura de ações de empresas. Em 2011, o espaço cresceu para $179.019 \mathrm{~cm} 2$ de matérias sobre o tema, totalizando mais de 850 reportagens. A conclusão é que a pauta tem sido cada vez mais transversalmente incluída.

\section{Considerações finais}

Ao fim deste estudo, é possível perceber que a linguagem e o discurso na Internet expressam muito mais uma continuidade do formato já existente nos veículos tradicionais do que uma proposição de linguagem própria, com suas características e possibilidades. Diante desse fato, fica clara a necessidade de observar e eleger novas e melhores estratégias 
discursivas dos conteúdos veiculados nas redes sociais e nas multiplataformas de comunicação.

Com o aumento da quantidade de aplicativos, sites e softwares, ampliam-se as possibilidades de interação dos formadores de opinião com seus públicos. Sendo assim, é preciso tirar proveito desses suportes tecnológicos de comunicação e de todas as suas funcionalidades para empreender novas estratégias discursivas. $\mathrm{Na}$ abordagem do tema da sustentabilidade, esse desafio amplia-se, haja vista que as novas formas de interação dos usuários com os conteúdos permitem novas formas de compreensão e engajamento nas causas.

O sujeito receptor da informação se transforma com muito mais velocidade, se transforma em categorias com multipossibilidades de conexão. Em tempos de jornalismo colaborativo, ou os sujeitos narradores se apressam para ampliar seus suportes de acesso e elegem novas prioridades narrativas, ou ficarão para trás e serão desbancados pelo leitorrepórter participante.

Por isso, formatar, conhecer e desenhar uma nova linguagem para essas mídias parece ser um desafio dos profissionais que atuam no âmbito do jornalismo digital, sobretudo quando se trata de sustentabilidade.

\section{Referências Bibliográficas}

BAMBRILLA, Ana (org). Para entender as Mídias Sociais. Walter Lima- autor do artigo Mídias Sociais Conectadas e Social Machines. Ano: 2011. Licença para o Creative Commons.

FERRARI, Pollyana. A força da mídia social: Interface e linguagem jornalística no ambiente digital. São Paulo: Fatash, 2010.

FERrari, Bruno e GUIMARÃES, Camila. 27 Pessoas que Você Precisa Conhecer. Revista Época, 2010, nº 628.

FRANCO, Augusto de. Escola de Redes: Tudo que é sustentável tem o padrão de rede. Sustentabilidade empresarial e responsabilidade corporativa no século 21. Curitiba: ARCA Sociedade do Conhecimento, 2008. Edição digital disponível em www.escoladeredes.org.br.

FRAGOSO, Suely, RECUERO, Raquel e AMARAL, Adriana. Métodos de pesquisa na internet. Porto Alegre: Sulina, 2011

JENKINS, Henry. Cultura da Convergência. São Paulo: Aleph, 2008.

LEFF, Enrique. Discursos Sustentáveis. São Paulo: Cortez, 2010. 
Manual de Etiqueta 3.0 - 65 ideias para enfrentar o aquecimento global e outros desafios da atualidade. Encarte elaborado pela Editora Abril e veiculado junto com as revistas Claudia, Contigo, National Geographic Brasil, Superinteressante, Veja e Viagem e Turismo, nos meses de junho e julho de 2011 .

SANTAELlA, Lúcia e LEMOS, Renata. Redes Sociais Digitais: a cognição conectiva do Twitter. São Paulo: Paulus, 2010.

SANTAELlA, Lúcia. Comunicação e Pesquisa: projetos para Mestrado e Doutorado. São Paulo: Hacker, 2001.

A ecologia pluralista das mídias locativas. Revista FAMECOS • Porto Alegre $\bullet n^{\circ} 37 \cdot$ dezembro de 2008 .

VAN PEBORGH, Ernesto. Odisea 2.0: Las Marcas e los Medios Sociales. Buenos Aires: La Crujía, 2010.

. Sustainability 2.0. Buenos Aires, 2008. Edição digital disponível em www.ecodesenvolvimento.org.br. 